\title{
Soil change induced by the application of biodigested vinasse concentrate, and its effects on growth of sugarcane
}

\author{
Juliana Silva $^{1^{*}}$, Jairo Cazetta ${ }^{1}$, and Aluisio Togoro ${ }^{1}$
}

\begin{abstract}
Vinasse (or stillage) is a byproduct from ethanol production, which contains organic matter, K, N, and other plant nutrients that is regularly used as soil fertilizer. However, high transportation costs limits its application in areas far from distilleries. The possibility of biogas production from vinasse, and the direct or indirect advantages of its use, is a way to reduce costs due to its concentration. Biodigested vinasse concentrate (BVC) is an alkaline product that is very different from common vinasse. Therefore, the objective of this study was to compare the effect of BVC with common vinasse $(\mathrm{CV})$ or $\mathrm{KCl}$, with or without $\mathrm{N}$ fertilization, on soil fertility and growth and nutrition of sugarcane (Saccharum officinarum L.) plants. Plants were grown in pots containing Oxisol under different treatments and maintained for $60 \mathrm{~d}$ under greenhouse conditions; variables related to soil fertility, plant growth, and mineral nutrition were evaluated. It was observed that adding BVC induces higher soil $\mathrm{pH}$ (5.9 to 6.3) and lower potential acidity (13 to $10 \mathrm{mmol}_{\mathrm{c}} \mathrm{dm}^{-3}$ ) compared with $\mathrm{KCl}$, and similar soil chemical changes to CV addition. Plants fertilized with BVC and N showed lower root dry matter (DM) (4.02 g) compared with those fertilized with $\mathrm{KCl}$ and $\mathrm{CV}$ (6.3 and $5.44 \mathrm{~g}$, respectively). Plants fertilized with BVC have similar total DM (18.25 and $20.31 \mathrm{~g}$ ) accumulation and nutritional conditions compared with those fertilized with $\mathrm{CV}$ and $\mathrm{KCl}$. Plants fertilized with BVC had the highest $\mathrm{Na}$ accumulation (0.36 and $\left.0.48 \mathrm{~g} \mathrm{plant}^{-1}\right)$.
\end{abstract}

Key words: Biodigestion, plant growth, Saccharum spp., soil fertility, stillage.

\section{INTRODUCTION}

In conventional ethanol production from sugarcane (Saccharum officinarum L.), each liter of ethanol produced results in approximately 12 to $15 \mathrm{~L}$ vinasse as a byproduct (Franco et al., 2008). Vinasse has high water content, organic matter $(\mathrm{OM})$, and potassium $(\mathrm{K})$, but also contains nitrogen $(\mathrm{N})$ and other mineral nutrients in low concentrations (Ribeiro et al., 2010). This byproduct is therefore regularly used as soil fertilizer in sugarcane fields with good results (Bebé et al., 2009; Britto et al., 2009; Silva et al., 2014). Due to its high water content, vinasse application in areas far from distilleries is limited by high transportation costs.

The possibility of using vinasse as a primary source for biogas production is a matter of interest since 1981, although the economic viability for different uses of the produced biogas is still a matter for discussion (Higa et al., 2014). Production and use of that energy source, or its indirect advantages (Szimanski et al., 2010; Solomon et

\footnotetext{
${ }^{1}$ Universidade Estadual Paulista (UNESP), Faculdade de Ciências Agrárias e Veterinárias, Rd. Prof. Paulo Donato Castellane s/n, 14884900, Jaboticabal, SP, Brasil.

*Corresponding author (jujuapsantos@ hotmail.com).

Received: 19 October 2014.

Accepted:15 March 2015.
}

doi:10.4067/S0718-58392015000200015 al., 2011), is a way to reduce costs due to the concentration of biodigested vinasse. This concentration could make transport viable and the application of $\mathrm{K}$ and other nutrients found in vinasse in areas where these nutrients were withdrawn during the sugarcane harvest. However, vinasse biodigestion changes its original composition.

The first change occurs by adding alkaline compounds to raise $\mathrm{pH}$ to optimize the biological process of methane production (Döll and Forest, 2010). Biodigested vinasse is an alkaline product. Another change is the loss of organic matter and some $\mathrm{N}$, which is clearly identified by the presence of $\mathrm{CH}_{4}, \mathrm{CO}_{2}$, and $\mathrm{N}_{2}$ in the released biogas (Ueno et al., 2013).

Although there is no precise information in the literature about the changes produced by the concentration process, it is expected that the high temperature used for water evaporation, associated with the effect of the alkaline medium, induces other changes that still remain unclear. It is well known that the $\mathrm{NH}_{4}{ }^{+}$ion changes into $\mathrm{NH}_{3}$ gas that easily volatilizes from the alkaline medium (Latifah et al., 2011).

These alterations lead to the hypothesis that part of the $\mathrm{NH}_{4}{ }^{+}$contained in the soil can be lost after biodigested vinasse concentrate (BVC) is applied, which could induce some differences in plant growth. Although vinasse contains a low $\mathrm{N}$ concentration, it is generally between $0.1 \mathrm{~g} \mathrm{~m}^{-3}$ (Silva et al., 2014) and $0.73 \mathrm{~g} \mathrm{~m}^{-3}$ (Carvalho 
et al., 2013) when applied at rates of $100 \mathrm{~m}^{3} \mathrm{ha}^{-1}$. These concentrations correspond to rates of 10 to $73 \mathrm{~kg} \mathrm{~N} \mathrm{ha}^{-1}$, which are considered as important values. Whether these amounts of $\mathrm{N}$ attributed to vinasse are relevant or not to sugarcane nutrition is still a matter for discussion (Franco et al., 2008). However, it has been shown that the balance between $\mathrm{K}$ and $\mathrm{N}$ is very important for sugarcane plant growth and ethanol production (Andrade Júnior et al., 2012).

Given the lack of studies on the use of BVC as a fertilizer, its effect on soil fertility and plant nutrition is unclear. Sugarcane growers are not sure about using this byproduct. More information is needed to support its use in sugarcane fields. Therefore, the objective of this study was to analyze the composition of BVC and compare its effect with common (in nature) vinasse $(\mathrm{CV})$ and $\mathrm{KCl}$ application in the absence and presence of $\mathrm{N}$ fertilization on soil chemical changes, and the effects on growth and nutrition of sugarcane plants.

\section{MATERIALS AND METHODS}

The experiment was conducted under greenhouse conditions in Jaboticabal ( $21^{\circ} 14^{\prime} 24^{\prime \prime}$ S, 48 $17^{\prime} 20^{\prime \prime} \mathrm{W}$; 583 m a.s.1.), São Paulo, Brazil. Treatments consisted of three $\mathrm{K}$ sources: $\mathrm{BVC}, \mathrm{CV}$, and $\mathrm{KCl}$ (all applied at rates equivalent to $450 \mathrm{~kg} \mathrm{~K}_{2} \mathrm{O} \mathrm{ha}^{-1}$ ), along with a control (no $\mathrm{K}$ application); these treatments were combined with two $\mathrm{N}$ levels (0 and $\left.30 \mathrm{~kg} \mathrm{ha}^{-1}\right)$. The experimental design was completely randomized with a $4 \times 2$ factorial scheme with four replicates for a total of 32 experimental units. Each experimental unit consisted of a $20 \mathrm{dm}^{3}$ capacity plastic pot containing $18 \mathrm{dm}^{3}$ soil where one sugarcane seedling was transplanted.

Before seedlings were transplanted, soil was limed to reach $60 \%$ of base saturation. After $60 \mathrm{~d}$ of liming, soil fertility was determined following indications by Raij et al. (2001), and values were: $\mathrm{pH}\left(\mathrm{CaCl}_{2}\right)$ 5.7; $\mathrm{OM} 4 \mathrm{~g} \mathrm{dm}^{-3}$; resin: $12 \mathrm{mg} \mathrm{P} \mathrm{dm}^{-3}$; $0.9 \mathrm{mg} \mathrm{K} \mathrm{dm}^{-3}, 16 \mathrm{mg} \mathrm{Ca} \mathrm{dm}^{-3}, 7 \mathrm{mg}$ $\mathrm{Mg} \mathrm{dm}^{-3}$, potential acidity $(\mathrm{H}+\mathrm{Al}): 11$, sum of bases $(\mathrm{SB})$ : 23.9, CEC (cationic exchange capacity) $34.9 \mathrm{mmol}_{\mathrm{c}} \mathrm{dm}^{-3}$, and V (base saturation) $68 \%$.

Along with soil preparation, sugarcane seedlings ('IACSP93-3046') were prepared by planting mini-cuttings (5 cm long) containing one bud each in disposable cups filled with $500 \mathrm{~cm}^{3}$ sand. The sand was moistened daily with tap water, and seedlings were kept under this condition for $60 \mathrm{~d}$ to deplete nutrients in the cuttings. Following the recommendation for fertilization when establishing sugarcane (Raij et al., 1997), $14.06 \mathrm{~g}$ superphosphate, corresponding to $180 \mathrm{~kg} \mathrm{P}_{2} \mathrm{O}_{5} \mathrm{ha}^{-1}$, was incorporated into the soil before planting. For $\mathrm{N}$ treatments, $0.85 \mathrm{~g}$ urea

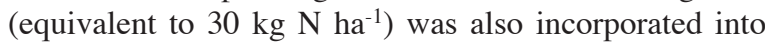
each pot. The most uniform seedlings were then selected, removed from the sand, and one seedling was planted in each pot. Potassium fertilizers were applied to the respective treatments $10 \mathrm{~d}$ after the planting date. The $\mathrm{K}$ rate applied by $\mathrm{CV}$ and $\mathrm{VC}$ follows the recommendation by Rossetto et al. (2008) when applying it to the total area. This rate is more economic and equivalent to three times more than what is recommended for mineral fertilizer applied to the rows, corresponding to a rate of $450 \mathrm{~kg}$ $\mathrm{K}_{2} \mathrm{O}$ ha $^{-1}$. To meet this recommendation, $0.196 \mathrm{dm}^{3} \mathrm{BVC}$, $2.0 \mathrm{dm}^{3} \mathrm{CV}$, and $9.7 \mathrm{~g} \mathrm{KCl}$ were applied to the soil of the respective treatments. Water was added to each pot with the calculated amounts of $\mathrm{BVC}$ and $\mathrm{KCl}$ to be applied to complete $2.0 \mathrm{dm}^{3}$ to prevent moisture differences among treatments. The chemical characteristics of BVC, CV, and diluted BVC are shown in Table 1.

Plants were cultivated for an experimental period of $60 \mathrm{~d}$ with daily irrigation with tap water. The amount of water applied was determined by weighing a few pots to estimate moisture loss and adding enough water to adjust them to approximately $60 \%$ soil water holding capacity. The following parameters were evaluated at the end of the experimental period: plant height (corresponding to the length between soil surface and insertion of the youngest fully expanded leaf, leaf +1 ), leaf number, tiller number, and leaf area. Leaf area was estimated by the formula: LA $=\mathrm{L} \times \mathrm{W} \times 0.75 \times(\mathrm{N}+2)$ where $\mathrm{L}$ is the length and $\mathrm{W}$ is the greatest width of the $3^{\text {rd }}$ fully developed leaf, 0.75 is the shape factor, and $\mathrm{N}$ is the number of fully expanded leaves with at least $20 \%$ green area added to a correction factor of 2 following the methodology proposed by Hermann and Câmara (1999). After these evaluations, leaf +1 was collected from each experimental unit and the midrib was removed and prepared to determine mineral nutrient content. Plants were then collected and packaged in previously identified paper bags.

Soil was passed through a sieve; a homogeneous soil sample from each pot was taken and prepared to determine fertility. The rest of the soil with roots was removed from the sieve with a jet of water to obtain a clean root system. Roots were washed again in water with detergent $(0.01 \%$ $\mathrm{v} / \mathrm{v}$ ) and then with tap water, packaged in identified paper bags, and prepared to determine dry weight. All plant samples were dried at 65 to $70{ }^{\circ} \mathrm{C}$ until constant weight and dry weight were determined. The DM of each plant sample was ground separately with a Wiley mill and passed through a 20-mesh sieve. The ground material was subjected to acid digestion to determine nutrient levels (AOAC, 1990).

The ANOVA was performed to detect significant differences $(\mathrm{P}<0.05)$ among treatment means and, the

Table 1. Chemical characteristics of biodigested vinasse concentrate (BVC), common vinasse (CV), and diluted BVC to reach a suspension with $\mathrm{K}$ concentration similar to common vinasse.

\begin{tabular}{|c|c|c|c|c|c|c|c|c|c|}
\hline Material & $\mathrm{pH}$ & $\mathrm{C}$ & $\mathrm{N}$ & $\mathrm{P}$ & $\mathrm{K}$ & $\mathrm{Ca}$ & $\mathrm{Mg}$ & $\mathrm{S}$ & $\mathrm{Na}$ \\
\hline & \multicolumn{9}{|c|}{$-\mathrm{g} \mathrm{dm}^{-3}$} \\
\hline $\mathrm{CV}$ & 4.00 & 18.00 & 0.14 & 0.05 & 2.30 & 0.34 & 0.17 & 0.04 & 0.10 \\
\hline BVC & 8.80 & 15.00 & 1.48 & 1.19 & 23.75 & 3.54 & 1.25 & 0.98 & 14.58 \\
\hline Diluted BVC & 7.80 & 1.46 & 0.14 & 0.11 & 2.30 & 0.34 & 0.12 & 0.09 & 1.41 \\
\hline
\end{tabular}


Tukey test was applied to establish significant differences $(\mathrm{P}<0.05)$ between mean values.

\section{RESULTS AND DISCUSSION}

The effects observed in the soil were changes in $\mathrm{pH}, \mathrm{K}$ and $\mathrm{Ca}$ contents, potential acidity $(\mathrm{H}+\mathrm{Al})$, and cation exchange capacity (CEC) as a result of applying K sources. Small changes in the CEC value were also detected because of $\mathrm{N}$ application (Table 2). The $\mathrm{pH}$ was higher in treatments that received BVC and CV. Soil that received these treatments also showed a lower concentration of $\mathrm{H}+\mathrm{Al}$. The increase in $\mathrm{pH}$ caused by $\mathrm{CV}$ application was also reported by Bebé et al. (2009) and Britto et al. (2009). The same effect was also observed in this experiment for BVC (Table 2). The increase in soil $\mathrm{pH}$ induced by adding vinasse occurs because OM contained in this residue has a good reducing potential (Britto et al., 2009); when reacting in the soil, it can increase the $\mathrm{pH}$ by neutralizing the proton $\mathrm{H}^{+}$in the soil solution. Biodigested vinasse concentrate had a lower $\mathrm{OM}$ concentration compared with $\mathrm{CV}$, but its $\mathrm{pH}$ was approximately 8.0 once $\mathrm{NaOH}$ was added to the original vinasse to improve conditions and optimize the biological process of methane production (Döll and Forest, 2010), which certainly contributed to increasing soil $\mathrm{pH}$.

Soil, which received $\mathrm{BVC}, \mathrm{CV}$, and $\mathrm{KCl}$, showed higher $\mathrm{K}$ concentrations than soil in the control treatment. Soil Ca concentrations with the BVC treatment showed an intermediate value that wasslightly lower than other $\mathrm{K}$ sources and higher than unfertilized soil.

The CEC values observed at the end of the experiment ranged between 32 and $37 \mathrm{mmol}_{\mathrm{c}} \mathrm{dm}^{-3}$; this is very close to the CEC value of $34.9 \mathrm{mmol}_{\mathrm{c}} \mathrm{dm}^{-3}$ initially obtained from the soil before treatments. In spite of that, soil that received $B V C$ showed a significantly $(P<0.05)$ lower value than other treatments. This result seems to occur once the CEC value in this research was calculated by the sum of bases $\mathrm{K}, \mathrm{Ca}, \mathrm{Mg}$, and potential acidity $(\mathrm{H}+\mathrm{Al})$; these values were slightly lower (some not significant at $\mathrm{P}=0.05$ ) for soil added with $\mathrm{BVC}$ and resulted in a lower $\mathrm{CEC}$ value. Given that part of the CEC value of tropical soils corresponds to variable charges coming from $\mathrm{OM}$ and that soil $\mathrm{pH}$ from the BVC treatment was higher than those from other $\mathrm{K}$ sources, it was to be expected that the CEC value for BVC would increase (Camargo et al., 1997), whereas the opposite result was found. Perhaps $\mathrm{Na}$ added to the soil by applying BVC might have influenced this result, and more appropriate studies are needed to confirm this effect and detect its possible cause. A low $\mathrm{CEC}$ value was also observed when $\mathrm{N}$ was applied (Table 2). Adding $\mathrm{N}$ induced greater plant growth (Tables 3 and 4) and improved nutrient absorption (Tables 6 and 7). Franco et al. (2007) explain that applying $\mathrm{N}$ can promote better macronutrient absorption by sugarcane because of synergism or improved root development, resulting in soil base depletion, which, in turn, can be reflected on the $\mathrm{CEC}$ value. The $\mathrm{P}, \mathrm{OM}$, and $\mathrm{Mg}$ contents, sum of bases $(\mathrm{SB})$, and base saturation $(\mathrm{V} \%)$ did not change $(\mathrm{P}>0.05)$ because of the treatments (Table 2).

Table 3. Effect of $\mathbf{N}$ levels on plant height, leaf area, and leaf dry matter of sugarcane plants.

\begin{tabular}{lccc}
\hline N levels & Plant height & Leaf area & Leaf dry matter \\
\hline & $\mathrm{cm}$ & $\mathrm{m}^{2}$ plant & \\
$30 \mathrm{~kg} \mathrm{ha}^{-1}$ & $32.07 \mathrm{a}$ & $0.18 \mathrm{a}$ & $\mathrm{g} \mathrm{plant}^{-1}$ \\
$0 \mathrm{~kg} \mathrm{ha}^{-1}$ & $30.04 \mathrm{~b}$ & $0.11 \mathrm{~b}$ & $15.75 \mathrm{a}$ \\
$\mathrm{F}$ test & $8.97^{* *}$ & $13.59^{* *}$ & $13.32 \mathrm{~b}$ \\
\hline
\end{tabular}

Different letters in columns indicate significant differences according to Tukey's test.

${ }^{* *} \mathrm{P}<0.01$ according to F-test.

Table 4. Effect of interaction among $\mathrm{K}$ sources (BVC, $\mathrm{KCl}$, and $\mathrm{CV}$ ) and control (without $\mathrm{K}$ source) versus $\mathrm{N}$ levels, on root dry matter (RDM) and total dry matter (TDM) per plant of sugarcane.

\begin{tabular}{|c|c|c|c|c|c|c|}
\hline \multirow[b]{2}{*}{ Variables } & \multirow[b]{2}{*}{$\mathrm{N}$ levels } & \multicolumn{4}{|c|}{ Treatments } & \multirow[b]{2}{*}{ F-test } \\
\hline & & Control & $\mathrm{KCl}$ & $\mathrm{CV}$ & BVC & \\
\hline \multirow[t]{3}{*}{ RDM, g } & $30 \mathrm{~kg} \mathrm{ha}^{-1}$ & $6.28 \mathrm{aA}$ & $6.30 \mathrm{aA}$ & $5.44 \mathrm{aAB}$ & $4.02 \mathrm{bB}$ & $4.68^{*}$ \\
\hline & $0 \mathrm{~kg} \mathrm{ha}^{-1}$ & $4.48 \mathrm{bA}$ & $4.75 \mathrm{bA}$ & $6.07 \mathrm{aA}$ & $5.66 \mathrm{aA}$ & $2.28^{\mathrm{ns}}$ \\
\hline & F test & $6.61^{*}$ & $4.9^{*}$ & $0.79^{\mathrm{ns}}$ & $5.49^{*}$ & \\
\hline \multirow[t]{3}{*}{ TDM, $g$} & $30 \mathrm{~kg} \mathrm{ha}^{-1}$ & $22.10 \mathrm{aA}$ & $23.46 \mathrm{aA}$ & $21.26 \mathrm{aA}$ & $18.25 \mathrm{aA}$ & $2.25^{\mathrm{ns}}$ \\
\hline & $0 \mathrm{~kg} \mathrm{ha}^{-1}$ & $15.59 \mathrm{bA}$ & $17.61 \mathrm{bA}$ & $20.72 \mathrm{aA}$ & $20.31 \mathrm{aA}$ & $2.69^{\mathrm{ns}}$ \\
\hline & F test & $9.8^{* *}$ & $7.92^{* *}$ & $0.06^{\mathrm{ns}}$ & $0.97^{\mathrm{ns}}$ & \\
\hline
\end{tabular}

Uppercase letters compare means within the rows and lowercase letters within the columns. Different letters indicate significant differences according to Tukey's test.

${ }^{* *} \mathrm{P}<0.01,{ }^{*} \mathrm{P}<0.05,{ }^{\mathrm{n} s} \mathrm{P}>0.05$ according to F-test.

$\mathrm{CV}$ : common vinasse, BVC: biodigested vinasse concentrate.

Table 2. Effect of $\mathrm{K}$ sources (BVC, $\mathrm{KCl}$, and $\mathrm{CV}$ ), control (no $\mathrm{K}$ source), and $\mathrm{N}$ levels on soil concentration of $\mathrm{P}$, OM, $\mathrm{K}$, Ca, and $\mathrm{Mg}$, as well as on soil pH $\left(\mathrm{CaCl}_{2}\right), \mathrm{H}+\mathrm{Al}$ (potential acidity), sum of bases (SB), percentage of base saturation (V), and soil exchange capacity (CEC).

\begin{tabular}{|c|c|c|c|c|c|c|c|c|c|c|}
\hline K sources & P-resin & OM & $\mathrm{pH}$ & $\mathrm{K}$ & $\mathrm{Ca}$ & $\mathrm{Mg}$ & $\mathrm{H}+\mathrm{Al}$ & SB & CEC & $\mathrm{V}$ \\
\hline & & $\mathrm{g} \mathrm{dm}^{-3}$ & & 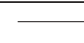 & $\mathrm{nmol}_{\mathrm{c}} \mathrm{dm}$ & ב & & & & \\
\hline $\mathrm{KCl}$ & $41 \mathrm{a}$ & $4 a$ & $5.9 \mathrm{~b}$ & $5.2 \mathrm{a}$ & $13 \mathrm{ab}$ & $6 a$ & $13 \mathrm{a}$ & $24 \mathrm{a}$ & $37 a$ & $65 a$ \\
\hline $\mathrm{CV}$ & $38 \mathrm{a}$ & $4 a$ & $6.1 \mathrm{ab}$ & $4.7 \mathrm{a}$ & $13 \mathrm{ab}$ & $7 a$ & $11 \mathrm{bc}$ & $24 \mathrm{a}$ & $35 a$ & $69 a$ \\
\hline BVC & $41 \mathrm{a}$ & $4 a$ & $6.3 \mathrm{a}$ & $4.3 \mathrm{a}$ & $11 \mathrm{~b}$ & $6 a$ & $10 \mathrm{c}$ & $22 a$ & $32 \mathrm{~b}$ & $68 a$ \\
\hline Control & $37 \mathrm{a}$ & $3 a$ & $5.9 b$ & $0.6 \mathrm{~b}$ & $15 \mathrm{a}$ & $8 \mathrm{a}$ & $12 \mathrm{ab}$ & $23 a$ & $35 a$ & $65 a$ \\
\hline F-Test & $0.4^{\mathrm{ns}}$ & $0.58^{\mathrm{ns}}$ & $10.79^{* *}$ & $19.91^{* *}$ & $5.09^{* *}$ & $3.59^{\mathrm{ns}}$ & $6.85^{* *}$ & $2.51^{\mathrm{ns}}$ & $5.70^{* *}$ & $2.37^{\mathrm{ns}}$ \\
\hline $\mathrm{N}$ levels & P-resin & OM & $\mathrm{pH}$ & K & $\mathrm{Ca}$ & $\mathrm{Mg}$ & $\mathrm{H}+\mathrm{Al}$ & SB & $\mathrm{T}$ & V \\
\hline $30 \mathrm{~kg} \mathrm{ha}^{-1}$ & $42 a$ & $4 a$ & $6.0 \mathrm{a}$ & $3.9 \mathrm{a}$ & $12 a$ & $6 a$ & $11 \mathrm{a}$ & $22 a$ & $33 b$ & $67 a$ \\
\hline $0 \mathrm{~kg} \mathrm{ha}^{-1}$ & $36 a$ & $4 a$ & $6.0 \mathrm{a}$ & $3.6 \mathrm{a}$ & $13 \mathrm{a}$ & $7 \mathrm{a}$ & $12 \mathrm{a}$ & $24 \mathrm{a}$ & $36 a$ & $67 a$ \\
\hline F-Test & $2.7^{\mathrm{ns}}$ & $4.45^{\mathrm{ns}}$ & $0.12^{\text {ns }}$ & $0.39^{\text {ns }}$ & $4.00^{\mathrm{ns}}$ & $6.51^{\mathrm{ns}}$ & $3.07^{\mathrm{ns}}$ & $4.85^{\mathrm{ns}}$ & $7.97^{* *}$ & $0.04^{\mathrm{ns}}$ \\
\hline
\end{tabular}

Different letters in the columns indicate significant differences according to Tukey's test.

${ }^{* *} \mathrm{P}<0.01,{ }^{\text {ns }} \mathrm{P}>0.05$ according to F-test.

$\mathrm{K}$ : potassium, CV: common vinasse, BVC: biodigested vinasse concentrate, N: nitrogen, P: phosphorus, OM: organic matter, Ca: calcium, Mg: magnesium, SB: sum of bases, V: base saturation, CEC: cationic exchange capacity. 
The DM of plants grown in soil treated with BVC showed values similar to those of plants in soil with $\mathrm{CV}$ and $\mathrm{KCl}$. However, $\mathrm{N}$ addition resulted in greater plant height, leaf area, and leaf DM, independently of the $\mathrm{K}$ sources used (Table 3$)$. The effect $(p<0.05)$ of the interaction among $\mathrm{K}$ sources and $\mathrm{N}$ levels was observed for root DM (RDM) and total DM (TDM) per plant; means are compared in Table 4. Although no difference $(\mathrm{P}>$ 0.05) was detected in TDM, plants that received BVC had lower RDM production than other $\mathrm{K}$ sources, especially when its application was associated with $\mathrm{N}$ fertilizer. This result can be a consequence of increasing electrical conductivity of the soil solution (Santana et al., 2007) as a result of the amount of $\mathrm{K}^{+}$and $\mathrm{Na}^{+}$from $\mathrm{BVC}$ associated with other ions originating from $\mathrm{N}$ fertilizer. However, $\mathrm{K}$ sources did not differ $(\mathrm{P}>0.05)$ for root $\mathrm{DM}$ production in the absence of $\mathrm{N}$ fertilization (Table 4). This indicates that the aerial part of the plants might have had a lower reduction than the roots, which leads to a nonsignificant difference $(\mathrm{P}<0.05)$ in TDM. Plants fertilized with $\mathrm{CV}$ and $\mathrm{BVC}$, independently of $\mathrm{N}$ levels, also showed values similar to TDM; this suggests that $\mathrm{N}$ from $\mathrm{CV}$ and BVC was enough to meet $\mathrm{N}$ plant demand until that time. Many studies have found that sugarcane has a low response to $\mathrm{N}$ fertilization. Nitrogen contributes approximately $1 \%$ of sugarcane TDM; however, $\mathrm{N}$ deficiency can cause a significant yield decrease (Franco et al., 2011). Leaf number and tiller number were similar $(\mathrm{P}>0.05)$ among plants from studied treatments with a mean number of leaves and tillers of 16.5 and 2.6 per plant, respectively.

The $\mathrm{K}, \mathrm{Ca}$, and $\mathrm{S}$ contents in plants were affected by $\mathrm{K}$ sources, independently of $\mathrm{N}$ levels (Table 5). Plant $\mathrm{K}$ contents were the same among treatments with BVC and CV. Treatments with CV and BVC were applied in equivalent amounts of $\mathrm{K}$, and results suggest that the availability of $\mathrm{K}$ from BVC satisfies the initial crop demand and its $\mathrm{K}$ availability is similar to $\mathrm{CV}$. Plants from BVC and CV treatments had lower Ca contents than those in the control treatment, possibly because of competition between cations, such as $\mathrm{Na}, \mathrm{Mg}$, and $\mathrm{K}$ at the time of absorption. For plant S content, BVC did not differ from

Table 5. Effect of $\mathrm{K}$ sources (BVC, $\mathrm{KCl}$, and $\mathrm{CV}$ ), control (without $\mathrm{K}$ source), and $\mathrm{N}$ levels on foliar contents of $\mathrm{N}, \mathrm{P}, \mathrm{K}, \mathrm{N}, \mathrm{Ca}, \mathrm{Mg}$, and $\mathrm{S}$ in sugarcane plants.

\begin{tabular}{lcccccc}
\hline K sources & $\mathrm{N}$ & $\mathrm{P}$ & $\mathrm{K}$ & $\mathrm{Ca}$ & $\mathrm{Mg}$ & $\mathrm{S}$ \\
\cline { 2 - 7 } $\mathrm{KCl}$ & $19.93 \mathrm{a}$ & $2.17 \mathrm{a}$ & $17.97 \mathrm{ab}$ & $5.00 \mathrm{a}$ & $1.67 \mathrm{a}$ & $2.39 \mathrm{~b}$ \\
$\mathrm{CV}$ & $20.02 \mathrm{a}$ & $2.11 \mathrm{a}$ & $19.39 \mathrm{a}$ & $3.90 \mathrm{~b}$ & $1.52 \mathrm{a}$ & $2.42 \mathrm{~b}$ \\
$\mathrm{BVC}$ & $20.60 \mathrm{a}$ & $2.16 \mathrm{a}$ & $19.06 \mathrm{a}$ & $3.96 \mathrm{~b}$ & $1.62 \mathrm{a}$ & $2.56 \mathrm{~b}$ \\
Control & $20.95 \mathrm{a}$ & $2.12 \mathrm{a}$ & $16.75 \mathrm{~b}$ & $4.46 \mathrm{ab}$ & $1.72 \mathrm{a}$ & $3.16 \mathrm{a}$ \\
F-test & $0.32^{\mathrm{ns}}$ & $0.11^{\mathrm{ns}}$ & $6.35^{* *}$ & $4.33^{*}$ & $1.68^{\mathrm{ns}}$ & $18.01^{* *}$ \\
N levels & & & & & & \\
$30 \mathrm{~kg} \mathrm{ha}^{-1}$ & $21.37 \mathrm{a}$ & $2.20 \mathrm{a}$ & $18.19 \mathrm{a}$ & $4.07 \mathrm{~b}$ & $1.58 \mathrm{a}$ & $2.77 \mathrm{a}$ \\
$0 \mathrm{~kg} \mathrm{ha}^{-1}$ & $19.38 \mathrm{~b}$ & $2.08 \mathrm{a}$ & $18.39 \mathrm{a}$ & $4.59 \mathrm{a}$ & $1.69 \mathrm{a}$ & $2.49 \mathrm{~b}$ \\
F-test & $5.45^{*}$ & $1.85^{\mathrm{ns}}$ & $1.18^{\mathrm{ns}}$ & $4.34^{*}$ & $2.91^{\mathrm{ns}}$ & $11.10^{* *}$
\end{tabular}

Different letters in the columns indicate significant differences according to Tukey's test.

${ }^{* *} \mathrm{P}<0.01,{ }^{*} \mathrm{P}<0.05,{ }^{\mathrm{ns}} \mathrm{P}>0.05$ according to F-test.

$\mathrm{CV}$ : common vinasse, $\mathrm{BVC}$ : biodigested vinasse concentrate.
$\mathrm{CV}$ and $\mathrm{KCl}$ treatments, but these treatments induced lower plant $\mathrm{S}$ concentrations than the controls.

Nitrogen levels also affected leaf $\mathrm{N}, \mathrm{Ca}$, and $\mathrm{S}$ contents of sugarcane. Higher $\mathrm{N}$ and $\mathrm{S}$ contents and lower $\mathrm{Ca}$ content were observed with $\mathrm{N}$ application. These results agree with the report by Vieira et al. (2010) about the positive effect of $\mathrm{N}$ fertilization on leaf $\mathrm{N}$ and $\mathrm{S}$ concentration, while the positive effect on $\mathrm{P}$ and $\mathrm{Mg}$ concentrations was not confirmed (Table 5). The synergistic effect between $\mathrm{S}$ and $\mathrm{N}$ in sugarcane was also observed by Franco et al. (2007). It occurs because $\mathrm{N}$ and $\mathrm{S}$ are components of the amino acids cystine and cysteine, so the increase in $\mathrm{N}$ supply implies a greater use of $\mathrm{S}$ by the crop. There was no difference $(\mathrm{P}>0.05)$ among treatments for $\mathrm{P}$ and $\mathrm{Mg}$ contents (Table 5). Equal amounts of all these nutrients were added, except $\mathrm{N}$, in all the treatments during substrate preparation. Potassium accumulation was separately influenced by $\mathrm{K}$ sources and $\mathrm{N}$ levels (Table 6). Although BVC was no different than other $\mathrm{K}$ sources, it tended to induce less plant $\mathrm{K}$ accumulation. The lower $\mathrm{K}$ accumulation in plants with the BVC treatment can be explained by the fact that BVC contains much more $\mathrm{Na}$ than other $\mathrm{K}$ sources, and given an antagonistic relationship between $\mathrm{Na}$ and $\mathrm{K}$, higher $\mathrm{Na}$ absorption could have reduced plant $\mathrm{K}$ absorption (Mansoori et al., 2014).

Higher $\mathrm{K}$ accumulation was observed in treatments with $\mathrm{N}$ application. It is possible that applying $\mathrm{N}$ can improve $\mathrm{K}$ absorption due to a synergistic effect on macronutrient absorption by sugarcane, which can increase nutrient accumulation in this plant (Franco et al., 2007). The effect ( $\mathrm{p} \leq 0.05)$ of the interaction among $\mathrm{K}$ sources and $\mathrm{N}$ levels in $\mathrm{N}, \mathrm{Ca}, \mathrm{Mg}$, and $\mathrm{S}$ accumulation was also observed (Table 7).

As expected, $\mathrm{N}$ fertilization induced greater $\mathrm{N}$ accumulation in plants. However, plants from the control treatment (no added $\mathrm{K}$ source) accumulated similar $\mathrm{N}$ amounts as in other $\mathrm{K}$ sources at each $\mathrm{N}$ level (Table 7). This suggests that the presence of $\mathrm{K}$ does not influence $\mathrm{N}$ absorption. Applying $\mathrm{CV}$ induced less $\mathrm{N}$ absorption by plants, which is reflected by no difference $(\mathrm{P}>0.05)$

Table 6. Effect of $\mathrm{K}$ sources (BVC, $\mathrm{KCl}$, and $\mathrm{CV}$ ), control (without $\mathrm{K}$ source), and $\mathrm{N}$ levels on $\mathrm{K}$ accumulation by sugarcane plants.

\begin{tabular}{lc}
\hline K sources & K accumulation \\
\hline & g plant $^{-1}$ \\
$\mathrm{KCl}$ & $0.50 \mathrm{a}$ \\
$\mathrm{CV}$ & $0.53 \mathrm{a}$ \\
$\mathrm{BVC}$ & $0.45 \mathrm{ab}$ \\
Control & $0.36 \mathrm{~b}$ \\
F-test & $7.81^{* *}$ \\
$\mathrm{~N}$ levels & \\
$30 \mathrm{~kg} \mathrm{ha}^{-1}$ & $0.50 \mathrm{a}$ \\
0 kg ha-1 & $0.42 \mathrm{~b}$ \\
F-test & $7.93^{* *}$ \\
\hline
\end{tabular}

Different letters in the columns indicate significant differences according to Tukey's test.

${ }^{* * *} \mathrm{P}<0.01$ according to F-test.

$\mathrm{CV}$ : common vinasse, BVC: biodigested vinasse concentrate. 
between plants with different $\mathrm{N}$ levels at the same $\mathrm{CV}$ rate (Table 7). Common vinasse has a high OM content with a high $\mathrm{C} / \mathrm{N}$ ratio; part of added $\mathrm{N}$ was possibly temporarily immobilized by soil microorganisms, which could have led to lower plant $\mathrm{N}$ availability and absorption.

Nitrogen fertilization induced plant $\mathrm{Ca}$ accumulation in the control treatment (without $\mathrm{K}$ addition) and plants in which $\mathrm{N}$ was associated with $\mathrm{KCl}$. In all $\mathrm{K}$ sources, plant $\mathrm{Ca}$ accumulation did not differ $(\mathrm{P}>0.05)$ in the absence of $\mathrm{N}$ fertilization. Data for $\mathrm{S}$ accumulation were similar to those obtained for $\mathrm{Ca}$ (Table 7). Potassium sources did not influence $(\mathrm{P}>0.05) \mathrm{Mg}$ accumulation in either the absence or presence of $\mathrm{N}$, while $\mathrm{N}$ application increased plant $\mathrm{Mg}$ accumulation in the control treatment. Franco et al. (2007) reported that $\mathrm{N}$ application can increase nutrient accumulation by sugarcane because it improves the development of the root system. Contact between roots and nutrients increases, which could improve plant nutrient absorption despite the fact that $\mathrm{P}$ accumulation was not affected by treatments $(\mathrm{P}>0.05)$ with an approximate mean of $0.04 \mathrm{~g} \mathrm{plant}^{-1}$. The effect ( $\mathrm{p}$ $<0.05$ ) of the interaction between $\mathrm{K}$ sources and $\mathrm{N}$ levels in $\mathrm{Na}$ accumulation was observed (Table 8). The BVC treatment induced higher plant $\mathrm{Na}$ accumulation because $\mathrm{BVC}$ has higher $\mathrm{Na}$ concentration than other $\mathrm{K}$ sources and the control (Table 1). These results are in accordance with information from the literature that reports $\mathrm{Na}$ as an element in which plant concentration increases due to salinity (Santana et al., 2007; Mansoori et al., 2014). This would be expected given added $\mathrm{NaOH}$ in the original vinasse to make $\mathrm{pH}$ suitable for the biodigestion process (Döll and Forest, 2010), which leads to high plant $\mathrm{Na}$ concentration from the BVC application.

Plants that received BVC showed the highest $\mathrm{Na}$ accumulation; however, $\mathrm{N}$ addition induced less plant $\mathrm{Na}$ accumulation in the BVC treatment. On the other hand, higher $\mathrm{Na}$ accumulation was detected in plants from other treatments that did not receive $\mathrm{N}$ addition. This

Table 7. Effect of interaction among $\mathrm{K}$ sources (BVC, $\mathrm{KCl}$, and $\mathrm{CV}$ ) and control (without $\mathrm{K}$ source) versus $\mathrm{N}$ levels on $\mathrm{N}, \mathrm{Ca}, \mathrm{S}$, and $\mathrm{Mg}$ accumulation by sugarcane plants.

\begin{tabular}{|c|c|c|c|c|c|c|}
\hline \multirow[b]{2}{*}{ Variable } & \multirow{2}{*}{$\begin{array}{l}\text { N levels } \\
\left(\mathrm{kg} \mathrm{ha}^{-1}\right)\end{array}$} & \multicolumn{4}{|c|}{ Control and $\mathrm{K}$ sources } & \multirow[b]{2}{*}{ F-test } \\
\hline & & Control & $\mathrm{KCl}$ & $\mathrm{CV}$ & BVC & \\
\hline \multirow[t]{2}{*}{$\mathrm{N}$, g plant $^{-1}$} & 30 & $0.29 \mathrm{aA}$ & $0.30 \mathrm{aA}$ & $0.24 \mathrm{aA}$ & $0.26 \mathrm{aA}$ & $2.40^{\mathrm{ns}}$ \\
\hline & 0 & $0.15 \mathrm{bA}$ & $0.18 \mathrm{bA}$ & $0.22 \mathrm{aA}$ & $0.20 \mathrm{bA}$ & $2.89^{\text {ns }}$ \\
\hline F-test & & $32.49^{* *}$ & $26.01^{* *}$ & $1.21^{\mathrm{ns}}$ & $5.29^{*}$ & F test \\
\hline \multirow[t]{2}{*}{$\mathrm{Ca}$, g plant $^{-1}$} & 30 & $0.09 \mathrm{aAB}$ & $0.11 \mathrm{aA}$ & $0.08 \mathrm{aB}$ & $0.08 \mathrm{aB}$ & $3.74^{*}$ \\
\hline & 0 & $0.06 \mathrm{bA}$ & $0.07 \mathrm{bA}$ & $0.07 \mathrm{aA}$ & $0.08 \mathrm{aA}$ & $2.22^{\mathrm{ns}}$ \\
\hline F-test & & $9.09^{* *}$ & $12.38^{* *}$ & $0.25^{\mathrm{ns}}$ & $0.25^{\mathrm{ns}}$ & F test \\
\hline \multirow[t]{2}{*}{ S, g plant ${ }^{-1}$} & 30 & $0.082 \mathrm{aA}$ & $0.062 \mathrm{aA}$ & $0.062 \mathrm{aA}$ & $0.057 \mathrm{aB}$ & $3.21^{*}$ \\
\hline & 0 & $0.045 \mathrm{bA}$ & $0.045 \mathrm{aA}$ & $0.065 \mathrm{aA}$ & $0.067 \mathrm{aA}$ & $3.95^{\mathrm{ns}}$ \\
\hline F-test & & $18.37^{* *}$ & $4.00^{\mathrm{ns}}$ & $0.08^{\mathrm{ns}}$ & $1.30^{\mathrm{ns}}$ & F test \\
\hline \multirow{2}{*}{$\mathrm{Mg}$, g plant ${ }^{-1}$} & 30 & $0.05 \mathrm{aA}$ & $0.04 \mathrm{aA}$ & $0.04 \mathrm{aA}$ & $0.04 \mathrm{aA}$ & $2.55^{\mathrm{ns}}$ \\
\hline & 0 & $0.03 \mathrm{bA}$ & $0.04 \mathrm{aA}$ & $0.04 \mathrm{aA}$ & $0.04 \mathrm{aA}$ & $2.09^{\mathrm{ns}}$ \\
\hline F-test & & $18.46^{* *}$ & $0.18^{\mathrm{ns}}$ & $0.00^{\mathrm{ns}}$ & $0.00^{\mathrm{ns}}$ & \\
\hline
\end{tabular}

Uppercase letters compare means within the rows and lower-case letters within the columns. Different letters indicate significant differences according to Tukey's test.

${ }^{* *} \mathrm{P}<0.01,{ }^{*} \mathrm{P}<0.05,{ }^{\text {ns }} \mathrm{P}>0.05$ according to F-test.

$\mathrm{CV}$ : common vinasse, BVC: biodigested vinasse concentrate.
Table 8. Effect of interaction among $\mathrm{K}$ sources (BVC, $\mathrm{KCl}$, and $\mathrm{CV}$ ) and control (without $\mathrm{K}$ source) versus $\mathrm{N}$ levels, on $\mathrm{Na}$ accumulation in the aerial part (leaves + stem), roots, and total in sugarcane plants.

\begin{tabular}{|c|c|c|c|c|c|c|}
\hline \multirow[b]{2}{*}{ Variables } & \multirow[b]{2}{*}{$\mathrm{N}$ levels } & \multicolumn{4}{|c|}{ K Sources } & \multirow[b]{2}{*}{ F-test } \\
\hline & & Control & $\mathrm{KCl}$ & $\mathrm{CV}$ & BVC & \\
\hline & \multicolumn{6}{|c|}{$\longrightarrow$ Na g plant ${ }^{-1}$} \\
\hline \multirow[t]{2}{*}{ Aerial part } & $30 \mathrm{~kg} \mathrm{ha}^{-1}$ & $0.12 \mathrm{aB}$ & $0.14 \mathrm{aAB}$ & $0.17 \mathrm{aAB}$ & $0.21 \mathrm{bA}$ & $4.42^{*}$ \\
\hline & $0 \mathrm{~kg} \mathrm{ha}^{-1}$ & $0.06 \mathrm{bB}$ & $0.07 \mathrm{bB}$ & $0.07 \mathrm{bB}$ & $0.29 \mathrm{aA}$ & $37.33^{* *}$ \\
\hline F-test & & $4.87^{*}$ & $7.74^{*}$ & $14.73^{* *}$ & $10.03^{* *}$ & \\
\hline \multirow{2}{*}{ Root } & $30 \mathrm{~kg} \mathrm{ha}^{-1}$ & $0.14 \mathrm{aB}$ & $0.08 \mathrm{aB}$ & $0.06 \mathrm{aB}$ & $0.15 \mathrm{bA}$ & $8.50^{* * *}$ \\
\hline & $0 \mathrm{~kg} \mathrm{ha}^{-1}$ & $0.08 \mathrm{bB}$ & $0.08 \mathrm{aB}$ & $0.07 \mathrm{aB}$ & $0.19 \mathrm{aA}$ & $16.21^{* * *}$ \\
\hline F-test & & $8.69^{* *}$ & $0.01^{\mathrm{ns}}$ & $0.01^{\mathrm{ns}}$ & $5.45^{*}$ & \\
\hline \multirow[t]{2}{*}{ Total } & $30 \mathrm{~kg} \mathrm{ha}^{-1}$ & $0.26 \mathrm{aAB}$ & $0.22 \mathrm{aB}$ & $0.23 \mathrm{aB}$ & $0.36 \mathrm{bA}$ & $5.91^{* * *}$ \\
\hline & $0 \mathrm{~kg} \mathrm{ha}^{-1}$ & $0.15 \mathrm{bB}$ & $0.15 \mathrm{aB}$ & $0.14 \mathrm{bB}$ & $0.48 \mathrm{aA}$ & $43.62^{* *}$ \\
\hline F-test & & $10.31^{\text {** }}$ & $3.82^{\mathrm{ns}}$ & $7.04^{*}$ & $11.70^{* *}$ & \\
\hline
\end{tabular}

Uppercase letters compare means within the rows and lower-case letters within the columns. Different letters indicate significant differences according to Tukey's test.

${ }^{* *} \mathrm{P}<0.01,{ }^{*} \mathrm{P}<0.05,{ }^{\text {ns }} \mathrm{P}>0.05$ according to F-test.

$\mathrm{CV}$ : common vinasse, BVC: biodigested vinasse concentrate.

result suggested that $\mathrm{N}$ application seemed to prevent $\mathrm{Na}$ absorption when BVC was used. Other authors have mentioned that $\mathrm{N}$ fertilization is used to attenuate the impact of salt stress in some species, and this also appears to be related to plant stress tolerance (Ehlting et al., 2007; Mansoori et al., 2014).

\section{CONCLUSIONS}

The addition of biodigested vinasse concentrate induces higher soil $\mathrm{pH}$ and lower potential acidity than $\mathrm{KCl}$, and causes similar soil chemical changes as when common vinasse is added. Plants fertilized with biodigested vinasse concentrate and $\mathrm{N}$ showed lower root dry matter, but had total dry matter accumulation and nutritional conditions similar to plants fertilized with common vinasse and $\mathrm{KCl}$. Plants fertilized with biodigested vinasse concentrate had higher levels of $\mathrm{Na}$ accumulation than common vinasse, $\mathrm{KCl}$, and unfertilized plants.

\section{ACKNOWLEDGEMENTS}

The authors thank the National Council of Scientific and Technological Development $(\mathrm{CNPq})$ for granting the master's scholarship to the first author (proc. 153437/2010-3) and the research scholarship to the second author (proc. 305 100/2009-2). The authors also thank the BPI-Biotechnical Processes International and the Usina São Francisco, Sertãozinho-SP sugar mill for the materials used in this project.

\section{LITERATURE CITED}

Andrade Júnior, A.S., E.A. Bastos, V.Q. Ribeiro, J.A.L. Duarte, D.L. Braga, e D.H. Noleto. 2012. Níveis de água, nitrogênio e potássio por gotejamento subsuperficial em cana-de-açúcar. Pesquisa Agropecuária Brasileira 47:76-84.

AOAC. 1990. Official methods of analysis of the Association of Official Analytical Chemists (AOAC). AOAC, Arlington, Virginia, USA. 
Bebé, F.V., M.M. Rolim, E.M.R. Pedrosa, G.B. Silva, and V.S Oliveira. 2009. Evaluation of soils under different periods of stillage aplication. Revista Brasileira de Engenharia Agrícola e Ambiental 13:781-787.

Britto, F.L., M.M. Rolim, and E.M.R. Pedrosa. 2009. Effect of vinasse application in chemical characteristics of soils from forest zone of Pernambuco. Revista Brasileira de Ciências Agrárias 4:456-462.

Camargo, O.A., O.M. de Castro, S.R. Vieira, e J.A. Quaggio. 1997. Alteração de atributos químicos do horizonte superficial de um latossolo e um podzólico com a calagem. Scientia Agricola 54:1-8

Carvalho, J.M., M. Andreotti, S. Buzetti, e M. de Passos e Carvalho. 2013. Produtividade de cana soca sem queima em função do uso de gesso e vinhaça. Pesquisa Agropecuária Tropical 43:1-9.

Döll, M.M., e E. Forest. 2010. Efeito do bicarbonato de sódio no tratamento de vinhaça em AnSBBR operado a 55 e $35{ }^{\circ} \mathrm{C}$. Engenharia Sanitária e Ambiental 15:275-282.

Ehlting, B., P. Dluzniewska, H. Dietrich, A. Selle, M. Teuber, R. Hänsch, et al. 2007. Interaction of nitrogen nutrition and salinity in Grey poplar (Populus tremula x alba). Plant, Cell and Environment 30:796-811.

Franco, H.C.J., I.R. Bologna, C.E. Faroni, A.C. Vitti, P.C.O. Trivelin. 2007. Macronutrients accumulation in sugarcane crop related to nitrogen fertilization and cultural residues incorporated to the soil at planting. Bragantia 66:669-674.

Franco, A., M.O. Marques, and W.J. Melo. 2008. Sugarcane grown in an Oxisol amended with sewage sludge and vinasse: nitrogen contents in soil and plant. Scientia Agricola 65:408-414.

Franco, H.C.J., R. Otto, C.E. Faroni, A.C. Vitti, E.C.A. de Oliveira, and P.C.O. Trivelin. 2011. Nitrogen in sugarcane derived from fertilizer under Brazilian field conditions. Field Crops Research 121:29-41

Hermann, E.R., e G.M.S. Câmara. 1999. Um método simples para estimar a área foliar da cana-de-Açúcar. STAB 17:32-34.

Higa, M., D.A. Calderani, e K.S. Lopes. 2014. Produção de energia elétrica produzida a partir da biodigestão da vinhaça de canade-açúcar - estudo de caso. Revista de Engenharia e Tecnologia 6:83-91.

Latifah, O., O.H. Ahmed, and A.M.N. Muhamad. 2011. Ammonia loss, ammonium and nitrate accumulation from mixing urea with zeolite and peat soil water under waterlogged condition. African Journal of Biotechnology 10:3365-3369.
Mansoori, M., M.A. Fazel, A. Jorfi, M. Mashal, and M. Mashal 2014. Effects of salinity stress on nutrient uptake of sugarcane genotypes. Nova Journal of Engineering and Applied Sciences 2:1-8.

Raij, B.V., J.C. de Andrade, H. Cantarella, e J.A. Quaggio. 2001. Análise química para avaliação da fertilidade de solos tropicais. 285 p. Instituto Agronômico, Campinas, São Paulo, Brasil.

Raij, B.V., H. Cantarella, J.A. Quaggio, e Â.M.C. Furlani (eds.) 1997. Recomendações de adubação e calagem para o estado de São Paulo. Boletim Técnico $\mathrm{N}^{\circ} 100.285$ p. Instituto Agronômico de Campinas, Campinas, São Paulo, Brasil.

Ribeiro, B.T., J.M. de Lima, L.R.G. Guilherme, and L.G.F. Julião. 2010. Lead sorption and leaching from an Inceptisol sample amended with sugarcane vinasse. Scientia Agricola 67:441-447.

Rossetto, R., F.L.F. Dias, A.C. Vitti, e S. Tavares. 2008. Potássio. p. 289-312. In Dinardo-Miranda, L.L., A.C.M. Vasconcelos, e M.G.A. Landell (eds.) Cana-de-açúcar. Instituto Agronômico de Campinas, Campinas, São Paulo, Brasil

Santana, M.J., J.A. Carvalho, K.J. de Souza, A.M.G. de Sousa, C.L. Vasconcelos, and L.A.B. Andrade. 2007. Effects of irrigation water salinity upon the sprouting and initial development of sugarcane (Saccharum spp.) and on soils with different textural levels. Ciência e Agrotecnologia 31:1470-1476.

Silva, A.P.M., J.A.M. Bono, e F.A.R. Pereira. 2014. Aplicação de vinhaça na cultura da cana-de-açúcar: Efeito no solo e na produtividade de colmos. Revista Brasileira de Engenharia Agrícola e Ambiental 18:38-43.

Solomon, K.B., E.E.S. Lora, M.H. Rocha, and O.A. del Olmo. 2011 Cost calculations for biogas from vinasse biodigestion and its energy utilization. Sugar Industry 136:217-223.

Szimanski, M.S.E., R. Balbinot, e W.N. Schirmer. 2010. Biodigestão anaeróbica da vinhaça: aproveitamento energético do biogás e obtenção de créditos de carbono - estudo de caso. Semina: Ciências Agrárias 31:901-912.

Ueno, C.R.J., L.M. Frare, M.L. Gimenes, e G.M. Zanin. 2013 Influência da adição fracionada de vinhaça na produção de biogás. Revista Brasileira de Biociências 11:115-118.

Vieira, M.X., P.C.O. Trivelin, H.C.J. Franco, R. Otto, and C.E Faroni. 2010. Ammonium cloride as nitrogen source in sugarcane harvested without burning. Revista Brasileira de Ciência do Solo $34: 1165-1174$. 